\title{
Brazilian Gothic: \\ Allegories of Tradition in Gilberto Freyre and the Catholic Novelists of the 1930s
}

\author{
By Fernando Monteiro de Barros*
}

This paper traces the intertextual presence of the eighteenth-century English gothic novel in the works of Brazilian sociologist Gilberto Freyre, notably The Masters and the Slaves (1933), and the novels by Brazilian Catholic writers Lúcio Cardoso and Cornélio Penna, who both depict a setting marked by emblems of a ruined patriarchic tradition that echo the splendour of a bygone monarchic and aristocratic past. In the context of 1930 Brazil, the decadent plantation manors of the once thriving coffee plantation areas of inland Rio de Janeiro and Minas Gerais stand as tropical counterparts of the haunted castles present in the gothic literary tradition, according to both Freyre's sociological study on Brazilian society and to Cardoso's and Penna's novels. Indeed, the focus of Brazilian Modernism on that decade begins to lie upon the tensions between tradition and modernity, in a country where the archaic coexisted with urban industrialization. In the same manner that it occurs in the English gothic novels, in which the imagery of tradition appears in a phantasmatic way, with the ruined castle as an allegory of the medieval past overthrown by modernity, the ruined plantation houses of Brazil's imperial and colonial times that are so recurring in Cardoso's and Penna's novels stand for the country's tradition supplanted by the Republic, which brought about the industrialization and the growth of the Brazilian bourgeoisie and its values. Taking a theoretical stance based on Walter Benjamin's concept of allegory in The origin of German tragic drama (1925), on Giorgio Agamben's reflections about the phantasmatic in Stanze: La parola e il fantasma nella cultura occidentale (1977), and on Matei Calinescu's various definitions of modernity in Five faces of modernity (1987), this paper focuses on a literary construct of "brazilianness" that derives from both a sociological point of view (Freyre's) and a literary European tradition (the Gothic).

According to literary canon, Gothic literature has its birthdate in 1764, exactly two hundred and fifty years ago, with the publication of The Castle of Otranto, subtitled "A Gothic Story" by its author Horace Walpole when it was

*Associate Professor, Rio de Janeiro State University, Brazil. 
reissued one year later. The genre has turned out to be as everlasting as a vampire, in its ability to survive and renew itself through the centuries, as the popularity of films and TV series can attest to the present day. Moreover, Gothic literature and its ramifications in the media as well as in popular culture have been the object of several academic studies.

Walpole's novel set the path for the utmost setting of the Gothic, the haunted (and often ruined) castle, scenario of "dark secrets" (MARSHALL, 2013: 3) where the aristocratic lord impersonates the villain amidst an atmosphere of oppressive gloom often connected with the supernatural. "If there is such a thing as a general topography of the Gothic, then its central motif is the castle", remark David Punter and Glennis Byron (2004: 259). It is curious to consider that the Gothic comes about in the age of Enlightenment, where reason, science, industrialization and democratic claims were in the process of tearing down the Ancien Régime and a whole array of traditional customs and values. It has often been pointed out by critics that the Gothic, with its emphasis on the medieval setting of the castle and the presence of the supernatural, comes to represent the repressed other, a ghost from the past to haunt the present. Here we aim to point out in the Gothic an allegory for tradition that coexists with modernity, like a dark and somber shadow of the latter.

Surprisingly as it may seem at first glance, the Gothic paradigm, associated primarily with the mists of Britain and northern Europe, can also be perceived in many a literary text produced in Brazil, a tropical South American country identified mostly with sun and sand. The Brazilian literature of the Romantic period started in Brazil as late as 1836, fourteen years after the country became independent from Portugal. The quest for nationalism, then, was a priority concern, and novelists and poets created an image of Brazil based on the lush tropical nature of the country. When Modernism came about in Brazil in 1922, the theme of nationalism based on the tropicalness of the land and its people was consolidated in the country's imagery. However, apart from this cliché construct of sunniness, one can come across some contradictions of this vast and complex nation. Indeed, one can find a certain construct of 'brazilianness' which shows another aspect of the country, as expressed by Gilberto Freyre, the Brazilian sociologist famous for his rendering of the pillars of Brazilian "civilization" in his best known study The masters and the slaves, published in Rio de Janeiro in 1933. Focused on the centuries that encompass the colonial and monarchic periods of Brazilian history - from the sixteenth to the nineteenth century -, Freyre explores the relation between the masters and the slaves of the agrarian monoculture society through what he considers to be a "tropical feudalism" (FREYRE, 1986: xi) centered on the plantation mansion, referred to as the "Big House", and the slave quarters, as expressed in the Portuguese title of the study, "Casa-grande e senzala". Curiously, as we propose to show in this paper, one can find in the Brazilian Big House construed by Gilberto Freyre startling similarities with the Gothic settings of the English eighteenth-century novels, and these similarities will play a strong part in the settings of the Brazilian literary novels written by 
a conservative yet transgressive 1930s group known as the Catholic novelists, of which Lúcio Cardoso and Cornélio Penna are the most outstanding names.

In the 1945 preface to the first English-language edition of The masters and the slaves, Gilberto Freyre establishes what he considers to be the symbol of Brazilian civilization par excellence, the feudal-like plantation with its manor and slave quarters:

The visiting foreigner cannot be said to have seen Brazil unless he has been in the old Big House of some sugar or coffee plantation, with what is left of its family silver, its rosewood, its porcelain, its ancestral portraits, its garden, its slave quarters, and its chapel filled with images of the saints and the mortal remains of former inmates. These Big Houses, slave quarters, and plantation chapels blend harmoniously with the fields of sugar cane, the coffee groves, the palm trees, the mangoes, the breadfruit trees; with the hills and plains, the tropical or semi-tropical forest, the rivers and waterfalls; with the horse-teams of the former masters and the oxen that were the companions in labor of the slaves. They likewise blend with those descendants of the white or near-white masters and of the Negro, mulatto, or cafuzo slaves who out of inertia have remained rooted in these old places where their grandfathers held aristocratic sway or engaged in servile toil. (FREYRE, 1986: xi)

It is interesting to notice the importance of the décor in Freyre's depiction of the Big House, which in a way echoes that of the Gothic castles, especially when it comes to the portraits of the ancestors. The idyllic construct of Freyre`s Brazil reminds us of the mythical antebellum American South, whose similarities to Brazilian agrarian society is acknowledged by the Brazilian sociologist, in his description of the socalled "deep South" as "a region where a patriarchal economy created almost the same type of aristocrat and of Big House, almost the same type of slave and of slave quarters, as in the north of Brazil and in certain portions of our own south", a region that has indeed "suffered and preserved the scars (when they are not open and still bleeding wounds)" (FREYRE, 1986: xxv). To which he adds: "every student of the patriarchal regime and the economy of slave-holding Brazil ought to become acquainted with the "deep South" (FREYRE, 1986: xxvi).

The American South, in its turn, has received some academic attention lately since it turns out to be the setting of what has been called Southern Gothic, as we can perceive in the words of David Punter and Glennis Byron:

Faulkner is often considered the progenitor of a subgenre called Southern Gothic, which appropriates elements of the traditional Gothic, combines them with the particular concerns of the American South, and is characterized by an emphasis on the grotesque, the 
macabre and, very often, the violent. Faulkner presents a Gothicized version of the American South, investigating madness, decay and despair, and the continuing pressures of the past upon the present, particularly with respect to the lost ideals of a dispossessed Southern aristocracy and to the continuance of racial hostilities. (PUNTER and BYRON, 2004: 116-117)

Jay Ellis, in his turn, points out that "the history of slavery remains so close to the dark provenance of Southern Gothic" (ELLIS, 2013: xx). The past of slavery and aristocratic lordship is, thus, a central element of this American Gothic subgenre, which leads us to propose a subgenre to Gothic called 'Brazilian Gothic' to refer to the same narratives that emphasize the Brazilian traditional setting of the Big House marked by the scars of slavery. As Bridget M. Marshall stresses about the Southern Gothic, saying that the setting shifts "from castle to plantation" (MARSHALL, 2013: 5), and adding that "what the American South lacks in medieval castles, it makes up for with plantations, often sprawling and in varying degrees of decrepitude" (MARSHALL, 2013: 6), we can also perceive in Freyre's construct of Brazil and, as we shall see, in the Brazilian Catholic novelists of the first half of the twentieth-century as well.

Besides the architectural space outlined above, the deeds of the masters towards the slaves also make up the fabric of Southern Gothic:

The physical architecture of these once grand plantations also works metaphorically, alluding to the dark history of these buildings and grounds. Gothic tales typically include a backstory that reveals the true history of such buildings, including the torture, rape, and other crimes committed against black slaves by their white masters. Actual slave plantations, as well as their renderings in Gothic fiction, frequently features secret rooms and even spaces specifically used for punishment of slaves. (MARSHALL, 2013: 7)

This same motif is also present in Gilberto Freyre`s portrayal of the Brazilian Gothic setting of the Big House, with the same crimes committed against the black slaves by the masters:

There is a legend in the northeast to the effect that a certain plantation-owner, more anxious than usual to assure the perpetuity of his dwelling, was not content until he had had a couple of slaves killed and buried beneath the foundation stones. The sweat and at times the blood of Negroes was the oil, rather than that of whale, that helped to give the Big House foundations their fortress-like consistency. (FREYRE, 1986: xxxv)

Let us point out that Freyre's study is a sociological one, not a literary work. Nevertheless, his style and the use of strong imagery give 
his work a literary flavor very much praised by his admirers but, on the other hand, much detracted by his critics, who also see in him a reproachable nostalgia for a bygone colonial and monarchic Brazil dependent on slavery. However, Freyre`s portrayal of agrarian Brazil will strongly influence the Brazilian regionalist novel of the 1930s, notwithstanding the socialist background of its authors. In that decade the country was in the very recent process of industrialization taken on since the times of the First World War and a frequent theme in Brazilian literature of the time was the friction between (agrarian) tradition and (industrialized) modernity.

As curious as one might think, indeed, in a sociological and anthropological study like The masters and the slaves, the supernatural, an important element of Gothic, also makes its presence, albeit in a hearsay manner, but ultimately contributing for the characterization of the Brazilian Big House as a Gothic setting, as Freyre brings to his study the addition of folk culture with its superstitions and anecdotes:

The Big house ghosts are in the habit of making their presence known by apparitions and noises that are practically the same throughout Brazil. A short while before the manor of Megaipe was stupidly demolished by dynamite, I had occasion to collect from the residents of the vicinity ghost stories connected with the old seventeenth-century dwelling. These tales had to do with the clatter of dishes heard in the dining-room; the rattling of swords; the swish and rustle of feminine silk; lights that were suddenly kindled and extinguished all over the house; moans and the clank of dragging chains; the weeping of a child; and apparitions of the grow-andshrink variety. Similar ghosts, so I was informed in Rio de Janeiro and in São Paulo, inhabit the ruins of the Big Houses in the valley of the Paraíba. (FREYRE, 1986: xxxix-xl)

Gilberto Freyre acknowledges that in twentieth century industrialized Brazil the Big Houses represent a ruin from what he perceives to be a glorious national past, as we can infer from his own words: "In Pernambuco the ruins of the big country house of the barons of Mercês are still to be seen, and it is evident that even the stables were built like fortresses. But all this pomp has long since turned to dust..." (FREYRE, 1986: xxxv)

In fact, Freyre is known for having been an avid reader of French decadent literature from the fin-de-siècle, and somehow the decadent theme of a civilization 'turned to dust' makes itself present in the style he uses to portray the origins of Brazilian civilization, as it stands for the country's tradition, in his point of view. In this sense, one can identify a subtle melancholy tone underneath the pages of The masters and the slaves.

Contemporary Italian philosopher Giorgio Agamben, upon the Freudian theme of the lost object, suggests that "covering its object with the funereal trappings of mourning, melancholy confers upon it the phantasmagorical 
reality of what is lost; but insofar as such mourning is for an unobtainable object, the strategy of melancholy opens a space for the existence of the unreal" (AGAMBEN, 1993: 20), to which he adds that "the imaginary loss that so obsessively occupies the melancholic tendency has no real object, because its funereal strategy is directed to the impossible capture of the phantasm", concluding that "the lost object is but the appearance that desire creates for its own courting of the phantasm..." (AGAMBEN, 1993: 25). According to the Italian philosopher's assertions, thus, we are encouraged to say that, in Gilberto Freyre's construct of Brazilian 'tradition', the big plantation house stands as a lost object invested with the trappings of the phantasm. In fact, in our opinion, that also goes for the quintessential Gothic setting of all, the ruined and haunted castle of English eighteenth century fiction.

As a representative of a bygone feudal past, the castle and the big plantation house, ruined and haunted, stand for allegories of tradition, in Walter Benjamin's sense of allegory expressed in his 1925 thesis The origin of German tragic drama. Indeed, Benjamin afirms:

"When, as is the case in the Trauerspiel, history becomes part of the setting, it does so as script. The word 'history' stands written on the countenance of nature in the characters of transience. The allegorical physiognomy of the nature-history, which is put on stage in the Trauerspiel, is present in reality in the form of the ruin. In the ruin history has physically merged into the setting. And in this guise history does not assume the form of the process of an eternal life so much as that of irresistible decay. Allegory thereby declares itself to be beyond beauty. Allegories are, in the realm of thoughts, what ruins are in the realm of things. This explains the baroque cult of the ruin." (BENJAMIN, 1998: 177-178)

While for Benjamin the symbol represents totality, since it stems from the original adamic language that, according to Jewish religious belief, was used by God to name all things created, the allegory, on the other hand, is associated with the fall of man and loss of Paradise, where language had no more the capacity to name and thence could only represent, arbitrarily, objects and creatures of this mundane world, fallen from Grace. The world of Modernity, marked by growing scientific and capitalistic values, devoid of transcendental comfort, could only thus be represented by allegories. As George Steiner remarks in his introduction to Benjamin's work, "only allegory, in that it makes substance totally significant, totally representative of ulterior meanings and, therefore, 'unreal' in itself, can render bearable an authentic perception of the infernal" (Apud BENJAMIN, 1998: 20). To this respect, Giorgio Agamben emphasizes that "one of the essential stylistic instruments of modern art [is] the nonfinished" (AGAMBEN, 1993: 32), quoting Schlegel, to whom "many works of the ancients have become fragments, and many works of the moderns are fragments at their birth" (AGAMBEN, 1993: 32). 
The 1930s which sees the publication of Gilberto Freyre`s Casa-grande e senzala is also known as the decade of the boom of the Brazilian modernist novel, whose main trend was regionalism in the fashion of Neo-Realism, in narratives usually set in the Brazilian agrarian Northeast that dealt with the exploitation of the poor, through a left-wing perspective, as we briefly mentioned above. Parallel to that literary mainstream, there was another group of Brazilian novelists that debuted in the 1930s whose main concern were the psychological aspects of man in a world characterized by mystery. Those were the Catholic novelists, the most prominent being Lúcio Cardoso and Cornélio Penna, as we said before.

Lúcio Cardoso begins his literary career in accordance with that mainstream tendency. His first two novels are neo-realistic, one set in the countryside and another set in a Rio de Janeiro slum. However, in 1936, Lúcio publishes A luz no subsolo, The light underground, a novel that takes a step away from Neo-Realism to portray not the social issue of class exploitation, but the psychological construction of the characters who struggle among themselves emotionally amidst a setting that resembles the haunted castles of the English eighteenth-century Gothic novels. Many of the clichés of this literary genre are present in this narrative, like the aristocratic villain, the persecuted maiden, the spying eyes, the nightly ambiance and the ruined castle, which, in this Brazilian novel, and echoing Freyre`s study, takes on the shape of a decaying colonial plantation Big House, a recurring setting in Lucio Cardoso's prose fiction.

Prominent Brazilian modernist writer Mário de Andrade, upon reading Lúcio's first psychological novel, confessed his bewilderment that the narrative had not focused on the political and social issues of the turbulent 1930s in Brazil and criticized the universalism of a setting that lacked tropical imagery, in the sunny sense. However, one does recognize in the novel an unmistakable Brazilian patriarchical background, derived from the "Gothic" aspects we have seen in Gilberto Freyre.

The novelty in Lúcio Cardoso's literary representation of Brazil, thus, is that it isn't through a solar or exotic point of view. The modernists of the 1920s, Mário de Andrade included, had put strong emphasis on the archaic, primitive aspect of the Brazilian culture, but through a naïve, optimistic point of view that goes along with the cliché vision of the country as a tropical paradise with a laid-back and carefree lifestyle taken place under the shade of the coconut trees. Despite Mário de Andrade's assertion, Lúcio Cardoso does indeed have a political stance when it comes to the representation of Brazil, which, in his novels, is depicted as a country where archaic forces of tradition live on in the twentieth-century, but, instead of light and joyful they are dark and melancholy.

In the same manner that in the English Gothic novels the imagery of tradition appears in a phantasmatic way, with the ruined castle as an allegory for the medieval past overthrown by modernity, the ruined plantation Big Houses of Brazil's colonial and monarchic times that are so recurring in Lúcio Cardoso's novels allegorically stand for the country's tradition supplanted by 
the Republic, which brought about the industrialization and the growth of the Brazilian bourgeoisie and its values.

Lúcio Cardoso was a great opposer of the bourgeoisie, and, at the same time, of its counterpart, socialism, in the same manner of Charles Baudelaire and the French decadent artists of the end of the nineteenth-century. Like them, Lúcio also identified himself with the aristocracy, although he wasn't an aristocrat himself. His view of brazilianness is, as we can see, strongly indebted to Gilberto Freyre's The masters and the slaves: a country defined by patriarchical relations that go back to the feudalism of colonial times. One may argue that Lúcio Cardoso was not a sociologist, and indeed he never aimed to be one, as his construct of brazilianness was of an aesthetic and poetical order, since it had many aspects in common with the construct of tradition seen in the Gothic narratives, as we have mentioned above. However, as we have seen, Freyre's sociological view of Brazil also harkens to those narratives, as indirectly and unconsciously as that may be.

One does get the wrong idea if one thinks that the content of the writings produced by the Catholic group was a moralistic one in a strait-laced manner. Theirs was a conception of Catholicism pretty much unorthodox, based much more on Baroque mysticism than on the moral standards of the Catholic middle-class, which they despised. Obsessed with the idea of salvation, they conveyed in their writings that salvation could only be attained through sin, paradoxically. In other words, for them the road to salvation was perdition. In the writings of Octavio de Faria, another member of the Catholic group, one could only aim to reach God's grace through sinning, as if one had to plunge in order to soar. In Lúcio Cardoso's point of view, God is thought to despise common sense and self-righteous behavior, and only the greatest of sinners could ever hope to obtain God's grace. Through this attitude, the Brazilian Catholic novelists of the 1930s showed an influence of both Baroque paradox and the quest for the lost absolute carried out by Romanticism. Needless to say, they were viewed by the conservative society of the time as much more perverted than religious.

Like the romantics, Lúcio Cardoso's quest was for the "truth", which, for him and his fellow writers, was not to be found in the legitimized discourse of western capitalism, represented by bourgeois and middle-class values and by the scientific and rationalistic paradigm. Neither was his vision of truth to be found in the leftist discourse of socialism and communism. In other words, Lúcio Cardoso was considered a complete misfit in the political scenario of the era he lived in. Nobody could understand him completely: he was deemed conservative by leftist intellectuals and perverted by the right-wing ones, at the same time. The label of "Catholic writer" failed to conform to common sense judgement, and therefore many were baffled by him.

Lúcio Cardoso, and the others in the Catholic group, actually belonged to a literary tradition that, in France, was represented by Georges Bernanos and Julien Green. Like Bernanos, Lúcio Cardoso was a monarchist and a Catholic who, in his writings, made sharp criticism of modern bourgeois society. Similar to Julien Green, who came from an aristocratic American family from the 
South, Lúcio identified himself with the defeated aristocracy overthrown alongside the Brazilian monarchy in the Republican coup of 1889. In his exploration of human psychology particularly in tortured souls, Lúcio shows a great influence of Dostoievsky. If we were to trace a parallel of Lúcio Cardoso's fiction with an American writer of the time, the name of William Faulkner, who wrote about the ruined aristocracy of the American South, would come to mind. And, indeed, as Faulkner is considered the chief writer of Southern Gothic, Lúcio Cardoso`s work also represents what we call 'Brazilian Gothic'.

In his defense of transgression as a path to salvation, in his denial of both bourgeois and socialist values, and in the aestheticism of his writings, Lúcio also resembles the decadent writers of the fin-de-siècle, like Joris Karl Huysmans, Oscar Wilde and Rúben Dario, who all descend from the same literary lineage of Charles Baudelaire, Théophile Gautier and Edgar Allan Poe, heirs to the Gothic tradition, since both the Gothic and the fin-de-siècle Decadence are viewed as 'evil twins'.

One needs to point out that transgression in the works of Lúcio Cardoso and the other Catholic writers of Brazil was a sexual one. Sexuality, as well as death, was the great obsession traced in Lúcio's novels, just as in English Gothic fiction. One can even sense a fascination with transgression itself in his writings, analogous to the fascination Baudelaire had for the lesbians and Huysmans and Wilde had for the femme-fatale. Curiously, the erotic metaphor Lúcio Cardoso employs most to convey repressed desire is vampirism. In the hallways and chambers of the ruined Brazilian plantation Big Houses, decayed aristocrats lurk in the dark waiting for their sexual preys to come by. In A luz no subsolo (The light underground), Pedro, heir to a ruined plantation and embodiment of the aristocratic villain of the Gothic novels, stalks Emanuela, a housemaid who fits the archetype of the persecuted maiden. Bernardo, Pedro's friend, in his turn, stalks Pedro's wife, Madalena. The narrative presents the erotic pursuit as a sudden vampire attack upon his prey and works the setting in accordance with the gloomy and sinister atmosphere of those eighteenth and nineteenth-century English narratives.

In $O$ desconhecido (The unknown one), published in 1940, the plot describes a young man, the "unknown one" of the title, who seeks employment in the Cataventos plantation. In the small village nearby nobody wants to give him directions to the whereabouts of the plantation, shaking their heads and shunning him as he asked. He decides to take a long road barefoot to the plantation. Halfway there, an old carriage appears, and inside is Aurélia, the aging plantation owner, covered in jewels but described as having the appearance of a bird of prey. The description of the carriage and of the long, claw-like jeweled fingers of Aurelia echoes those of the narratives of terror. The carriage and the plantation Big House stand here for symbols of the bygone past of the Brazilian colonial and monarchic times, supplanted by twentieth-century modernity. In relation to the unknown man who seeks a job in her plantation, Aurelia adopts a seductive and predatory behavior. Her plantation manor boasts a decaying splendor of an anachronic scenario that 
stands for a dead era, the dead era of the Brazilian monarchy, when coffee plantations thrived with the labor of the slaves and the presidency of their aristocratic landlords, who, in Brazil, were given titles of nobility by the Emperor. Aurelia is characterized as grotesquely ugly, an aging aristocratic lady, but dressed up in regal nineteenth-century gowns, making her resemble a ghost from the past. Through the end of the narrative, she ultimately stalks the unknown man, whom she had arbitrarily decided to name José Roberto, in the corridors of the haunted manor, like a vampiress.

"In Cornélio Penna's novel A Menina Morta (The Dead Girl, 1954), we see a Brazil that does not belong to yesterday, as many would think, but a Brazil that is eternal in its roots and in its tragedy. I do not know of any other [Brazilian] writer who can bring us back the flesh and the soul of a lost country, beset today with foreign evils which are deprived of any grandeur", so we read in Lúcio Cardoso's review of Cornélio Penna's novel published in the literary magazine Revista da Semana, in February the 5th, 1955 (BARROS, 1994). Cornélio Penna's novel is set in a nineteenth-century Brazilian coffee plantation and the characters are the masters and the slaves. The plantation Big House is described as somber, where ghosts slide through even during the day. The lord and the lady who there preside are described as sinister vampire figures, all clad in black. The "dead girl" of the title, an infant heiress whose death is ominous of the coming fall of the Brazilian monarchy, stands as an allegory of this construct of brazilianness dear to Lúcio Cardoso, set upon traditional, Freyrean Brazil.

In the novel that is considered his masterpiece, Crônica da casa assassinada, Chronicle of the Murdered House, published in 1959, Lúcio Cardoso describes the decay of an aristocratic family, the Meneses, in the first half of the twentieth-century. The novel presents all of Lúcio Cardoso's demons and obsessions: incest, homosexuality, the concept that good is reached through evil, the construct of a Gothic brazilianness that survives as a ghost of the past in modern times. Here, too, the "murdered house" of the title is an allegory of a lost Brazil, that replaced monarchic and aristocratic grandeur for bourgeois and middle-class values and capitalism, in Lúcio Cardoso's romanticized point of view. In a way, the narrative echoes Edgar Allan Poe's "The Fall of the House of Usher". One of the heirs to the ruined plantation is Timóteo, who is locked in his room by the family because he dresses up in his deceased mother's clothes. Timóteo points out that one of their ancestors, Maria Sinhá, used to walk freely in the plantation dressed as a man, in the time the family and the plantation had reached their full splendor. The analogy is clear: the decay is a consequence of the adoption of bourgeois, middle-class moral values and standards by the aristocratic family, who, under such mistake, is ashamed of its "monstrous" member, doomed to be imprisioned in his room, like "the madwoman in the attic" of Gothic fiction. There is incest between mother and son. One of the most noteworthy characters is Ana, who is always clad in black but adopts a predatory, vampire-like sexuality due to repression. Another character is a priest who claims that "the utmost $\sin$ is not to sin" and 
that "God many times takes on the face of evil". Many literary critics labeled the novel as "immoral" at the time.

As David Punter and Glennis Byron point out, a family curse is "a characteristic Gothic motif since Horace Walpole`s The Castle of Otranto", as Gothic fiction often "focuses on family secrets and the immediate past of its transgressive protagonists" (PUNTER and BYRON, 2004: 29). Bridget M. Marshall adds that "as inaugurated by Walpole's novel, a primary theme of the Gothic is a concern that "the sins of the fathers are visited upon their children"" and the "crime of incest" constitutes a typical form of transgression in Gothic narratives (MARSHAL, 2013: 8). In Lúcio Cardosos`s Crônica da casa assassinada, as we can thus notice, the transgression of social taboos concurs with the setting to make this a true example of Brazilian Gothic.

Although Lúcio Cardoso has been considered an anti-modernist by some literary critics, he shares a conception of modernity mingled with the idea of decadence that goes back to the Romantics, the first modern aesthetes, according to Matei Calinescu's remarks: "the critique of the myth of progress was started within the romantic movement, but it gained momentum in the antiscientific and antirationalist reaction that marks the late nineteenth century and prolongs itself well into the twentieth" (CALINESCU, 1987, p. 156).

One hears often that Brazil is a country devoid of memory, obsessed by the idea of future redemption for its several economic and social shortcomings. Modernism is greatly acclaimed in the country, with its emphasis on popular culture, native folklore and industrialization. The agrarian colonial and monarchic past of the Big House and the slave quarters is considered something to be ashamed of and the reason for the country`s backwardness. When the Republic was proclaimed in 1889 much was done to forsake the past. However, the social injustices of the slave quarters still persist in modern day urban favelas, slum dwellings. Brazilian Gothic shows that, in a persistent aporia, the country should come to terms with the sins of the past to better understand itself and, at least, recognize its also dystopian connection to Western literature and culture. In a Gothic way of thinking, no matter how progressive, urbanized or scientifically developed Brazil eventually gets, the ghosts of the Big House will always be there to cast a haunting shadow on the sandy and sunny beaches, as the writings of Gilberto Freyre, Cornélio Penna and Lúcio Cardoso seem to keep saying again and again.

\section{References}

Agamben, G. 1993. Stanzas. Word and phantasm in Western culture. Translated by Ronald L. Martinez. The University of Minnesota Press, Minneapolis.

Barros, F. M. de. 1994. Aristocracia e monstruosidade: nostalgia da aura na Crônica da casa assassinada de Lúcio Cardoso. Master's Dissertation. Universidade Federal do Rio de Janeiro, Brazil. 
2002. Vampiros na casa-grande: clausura e poses do gótico em Lúcio Cardoso. Doctoral Thesis. Universidade Federal do Rio de Janeiro, Brazil.

Benjamin, W. 1998. The origin of German tragic drama. Translated by John Osborne. Verso, London.

Bosi, A. 1999. História concisa da literatura brasileira. Cultrix, São Paulo.

Calinescu, M. 1987. Five faces of modernity. Duke University Press, Durham, NC.

Ellis, J. 2013. “On Southern Gothic Literature”. In ELLIS, J. (editor). Southern gothic literature (Critical insights). Salem Press, Ipswich, Massachussetts and Grey House Publishing, Amenia, NY.

Freyre, G. 1986. The masters and the slaves. A study in the development of Brazilian civilization. Translated from the Portuguese by Samuel Putnam. University of California Press, Berkeley.

Marshall, B. M. 2013. "Defining Southern Gothic". In ELLIS, J. (editor). Southern gothic literature (Critical insights). Salem Press, Ipswich, Massachussetts and Grey House Publishing, Amenia, NY.

Moser, B. 2009. Why this world: a biography of Clarice Lispector. Oxford University Press, Oxford.

Praz, M. 1991. The Romantic agony. Translated by Angus Davidson. Oxford University Press, Oxford.

Punter, D. and Byron, G. 2004. The Gothic. Blakwell Publishing, Oxford.

Williams, A. 1995. Art of darkness: a poetics of Gothic. The University of Chicago Press, Chicago. 